\title{
Immunotherapy in Cancer Treatment
}

\author{
Aaron J. Smith, John Oertle, Dino Prato \\ Envita, Scottsdale, AZ, USA \\ Email: Aaron@Envita.com, JohnO@envita.com, DinoPrato@envita.com \\ Received 4 July 2014; revised 5 August 2014; accepted 4 September 2014 \\ Copyright (C) 2014 by authors and Scientific Research Publishing Inc. \\ This work is licensed under the Creative Commons Attribution International License (CC BY). \\ http://creativecommons.org/licenses/by/4.0/ \\ cC) (i) Open Access
}

\begin{abstract}
Various kinds of immunotherapy treatment for cancer are either available to the public or are in the process of clinical trials. Immunotherapy treatments have the potential to treat cancer with significantly less toxicity than chemotherapy and radiation treatments. An emphasis on cellular infusion as a method of either enhancing the immune system by creating an environment for sequestering the host immune system to attack cancer cells or more directly inserting cells to directly attack cancer cells will be provided in this review. Various forms of cancer vaccines are also discussed in this paper as an important aspect in immunotherapy. This review seeks to describe various methodologies associated with administering immunotherapy in the treatment of cancer.
\end{abstract}

\section{Keywords}

\section{Immunotherapy, Cancer, T-cell, NK Cell, Dendrite, CIK, Nano Particles, Exosomes}

\section{Introduction}

The three traditional methods of treating cancer are surgery, chemotherapy, and radiation. These methods may fail to completely remove or eradicate neoplastic cells or cancer stem cells. These methodologies are not specific and have the potential to damage healthy tissue which can lead to morbidity and even mortality. The immune system itself can be greatly impacted by chemotherapy and radiation, leaving the immune system response to cancer degraded.

The ability to restock or enhance the immune response to cancer is very important following chemotherapy and radiation. The immune system protects against cancer in a few ways. One way is the ability of the immune cells to fend off pathogens that are also known carcinogens. Nearly $20 \%$ of all cancers are caused by carcinogenic microorganisms. Some of these pathogens, if unregulated by the immune system, can lead to cancers that include but are not limited to Hepatitis B and C, Epstein Barr virus, chlamidia pneumonia, merkel cell plyoavirus, and salmonella typhi-1. The immune system can also regulate inflammation which is associated with the development of cancer. Lastly, the immune system can regulate cancer cells themselves through tumor immune 
surveillance. This involves the immune system recognizing precancerous and cancerous cells and eliminating them before they become harmful.

There can be a balance of the immune system response to cancer and cancer development called cancer immunoediting. This is a dynamic process where the immune system regulates cancer in one of three different phases. These phases include elimination, equilibrium, and escape. The elimination phase is where the cancer or precancerous cells are detected by the immune surveillance and essentially eliminated [1]. If the cancer cells cannot be completely eliminated, then an equilibrium occurs where the immune system essentially keeps the cancer in check by eliminating as much as it can while the cancer develops. At some point the cancer cells either mutate to avoid immune surveillance [2] [3], fight back with various chemicals that can inhibit the immune response, and/or create a tumor microenvironment where the acidity surrounding the cancer further inhibits the immune response.

Innate immune response is an important factor in controlling the spread of cancer. The innate response involves the use of natural killer cells, macrophages, dendritic cells (DC), and DC/T-cell response. Natural killer cells include CD3-, CD16+, and CD56+ and have the potential to recognize and eliminate tumor cells via perforin/granzyme, and can induce apoptosis in a variety of cell lines. Macrophages, in particular M1 macrophages, have the capacity to kill tumor cells by secreting inflammatory cytokines which can exert cytotoxic activity in addition to tumor-destructive reactions [4]. DCs are responsible for generating a tumor specific effect or immune responses and are an essential link between the innate and adaptive immune response. DCs interact with naive $\mathrm{T}$ lymphocytes in a process involving different cellular signals to establish effector T-cells [5]. The process involves four steps and includes antigen presentation, co-stimulatory molecules, cytokine signaling, and chemokine signaling.

The adaptive immune response involves the recognition of antigens presented by MHC- 1 and MHC-2 by several kinds of T lymphocytes which include CD8+ cytotoxic T lymphocytes (CD8+ CTL) and CD4 T helper ( $\mathrm{T}_{\mathrm{H}}$ ) cells. Adaptive immune responses are longer lasting with regard to remembering antigens presented to them by MHC-1 and MHC-2 respectively. CD8+ T-cells secrete IFN- $\gamma$, perforin, and granzyme B which enact cytolytic activity on cancer cells in addition to playing an important role in immune surveillance. CD4+ T-cells are divided into several subtypes and into $\mathrm{T}_{\mathrm{H}} 1 \mathrm{~T}_{\mathrm{H}} 2$ phenotypes. $\mathrm{T}_{\mathrm{H}} 1$ cells collaborate with CD8+ T-cells in addition to secreting IFN- $\gamma$, TNF- $\alpha$, and IL-2 [6], promoting the presentation on MHCI and MHCII and the up regulation of antigen processing. $\mathrm{T}_{\mathrm{H}} 2$ fosters humoral immune response by associating with B-cells [7].

\subsection{Genetically Modified Dendritic Cells}

There are several reasons why the immune system's protection against cancer is so challenging. This includes aberrantly tumor associated antigens [8]-[12] which are associated with natural immunological tolerance of cancer cells and tumor induced immune suppression [13]. Dendritic cells are major regulators of the immune system [9] [14] [15] as well as stimulators or inhibitors of T-cells and B-cells [16]. Constructing dendritic cells to recognize and support an immunological response against cancer cells is challenging and involves changing the intercellular responses to tumor associated antigens and the relaying a signal to T-cells and B-cells. Lentiviral constructs are used to present dendritic cells with new genes that can alter the intracellular pathways associated with creating a robust immune response. Antigen presentation of cancer associated antigens involves a 3 signal model [17] [18]. The mechanism involves the binding of T-cells to form a complex associated with antigen presentation by major histocompatibility molecules and antigen peptides found on dendritic cells as well as responding to co-stimulatory molecules is significant for recognition of self and non-self epitopes. The selection of co-stimulatory molecules in dendritic cells are a major target for enhancing an immune response against cancer since without the co-stimulatory molecules, T-cells will automatically be programmed for apoptosis, anergy, or exhaustion.

Modulation of T-cell response by selective targeting of intracellular signaling pathways is complicated and often results in a new phenotype of dendritic cells. Activation of MAPK/IRF3 increased the secretion of immunosuppressive cytokines [14]. Subcutaneous vaccination of modified dendritic cells by expressing p38 or JNK1 activators significantly increased the CD8 and CD4 cellular expansion [14]. Although p38-activated dendritic cells take approximately 7 days to activate T-cell, complete regression was evident with the caveat of having some of the tumors grow back after dendritic cells lost expression of OVA [14]. Lentiviral constructs to promote a blockade of PD-L1/PD-1 interaction in DC has a stimulatory effect with regard to the interaction of T-cells in 
addition to increasing the infiltration of T-cells in tumors [19] [20]. The combination of expressing p38 in addition to PD-L1 silencing in DC yielded an increase IFN- $\gamma$ T-cell expansion in addition to a decrease in tumor size while increasing survival time [21]. After 3 months, the cure rate was about $80 \%$ for the EG7 lymphoma model [20] [22].

\subsection{Stem Cell Immunotherapy}

Immunotherapy through the use of stem cells remains in its infancy and has yet to become as focused as other forms of immunotherapy. The pluripotent characteristics allow stem cells to become virtually any kind of cell. Some stem cell therapies include inducing stem cells to produce dendritic cells, natural killer cells, and antigen specific T-cells. The differentiation of dendritic cells has been accomplished in both mouse and human ES cell lines [23] [24]. These dendritic cells were functional but had limited ability for cross presentation of antigens to CD8+ T-cells MHC. Differentiation of ES cells to form antigen specific naïve T-cells has been produced by a combination of transcription factors and the introduction of fetal thymus organ culture in order to provide an environment conducive for the formation of diverse CD4+ and CD8+. There have also been reports of successfully differentiated induced pluripotent stem cells to form antigen specific T-cells that can recognize the epitope of melanoma antigen MART-1 [25]. Natural Killer cells have been derived from induced pluripotent stem cells in a two stage culture system [26]. One of the advantages of creating NK cells from stem cells is that it does not require the cell sorting associated with acquiring NK cells in ex vivo. NKT cells have also been differentiated from iPS cell lines. Although these cell lines certainly play a role in the immune system response to fight cancer cells, these cell lines have not been introduced to patients in clinical trials.

\section{Tumor Infiltrating Lymphocyte Immunotherapy}

Tumor infiltrating lymphocytes (TIL) are a heterogeneous mixture of lymphocytes that are found growing within a tumor. TILs are predominately ineffective for killing the cancer cells within the tumor for a number of reasons including a high number of immunosuppressive $\mathrm{T}$ regulatory cells, a low number of anti-tumor cells, or anti-tumor cells that have become deactivated or anergic.

Immunotherapy using TIL involves the removal of the TILs from the tumor microenvironment before inducing the growth of these cells in vitro and then delivering them back into the body to combat the cancer. Lymphodepletion is thought to increase the activity of the TILs in addition to removing immunosuppressive T-reg cells in order to create an environment that is more conducive for the TILs to combat cancer [27] [28]. This process may even reduce the competition of IL-7 and IL-25 [29] and create space for the proliferation of TILs including NK cells.

Treatment involving TIL therapy has shown itself to be one of the most effective forms of immunotherapy [30]-[32]. The objective response rate varies between $51 \%-72 \%$ for patients in the advanced stage of melanoma following aggressive treatment involving chemotherapy and often radiation [33] [34]. The TILs effectiveness involves the clinical response time, with regard to the time it takes to culture the TILs which subsequently affects the length of telomere of TILs [35]-[39]. In addition to younger TILs with longer telomeres, they also have higher levels of costimulatory molecule including CD27 and CD28, which is associated with greater persistence in vivo [37]-[41].

\subsection{Natural Killer Cell Immunotherapy}

Natural killer (NK) cells, also known as CD56+ and CD3+, are lymphocytes with cytotoxic potential against anti-self cells. NK cells can be activated and inhibited via several receptor-ligand interactions depending on whether the cells encounter self or anti-self MHC antigens [42] [43]. Licensing via KIR receptor is an important step with regard to how NK cells recognize anti-self cells before they can be fully activated [44]-[46]. NK cells have anti-cancer characteristics but can also be attenuated by either molecules secreted by cancer cells or the cancer micro-environment acidity can paralyze the cells [47] [48].

Autologous NK cell infusion is clinically ineffective with regard to its cancer fighting ability even in the presence of interlukin IL-2 [49]-[51]. However, allogenic NK transfusion has shown some promise with minimal cytotoxicity [52]. CD3-depleted NK lymphocytes with prior doses of cyclophosphamide and fludarabine with additional IL-2 injections following the CD56+ infusion resulted in five out of 19 patients with a poor prognosis 
of acute myeloid leukemia had remission [53]. A study containing 10 children with AML were treated with T-cell depleted CD56+ after being treated with chemotherapy and all of the children were in remission for at least 2 years [54].

\subsection{Natural Killer T Cell Immunotherapy}

Natural Killer T (NKT) cells are able to bridge the gap between the innate and adaptive immunity by establishing memory responses in addition to improving protective immune response. NKT cells are characterized by their antigen receptor $\mathrm{V} \alpha 14 \mathrm{j} \alpha 18$ in mice and $\mathrm{V} \alpha 24 \mathrm{j} \alpha 18$ in humans [55]-[57]. The NKT cell is activated by the $\alpha$-galactosylcermide ( $\alpha$-GalCer) ligand which results in the expansion of NKT cells which in turn inhibit the growth of metastatic lung cancer and liver metastasis in melanoma in vivo mouse models [58] [59]. Mice with induced liver metastasis and treated with $\alpha$-GalCer/DCs resulted in complete remission of liver metastasis a week after treatment [60]. After surgery, chemotherapy, and radiation, seventeen non-small cell lung cancer patients, who had their peripheral blood mononuclear cells (PBMC) cultured for a week before being pulsed with $\alpha$-GalCer, were administered their autologous and induced NKT cells twice in the period of a week [61]. Of the 17 patients who underwent this treatment, 10 patients had prolonged their median survival time to 29.3 months as compared to the group without IFN- $\gamma$ producing cells who had a median survival time of 9.7 months even though either group did not show significant tumor regression [62]. The clinical study had remarkably low levels of toxicity.

\subsection{Cytokine Induced Killer Cell Immunotherapy}

Cytokine induced killer (CIK) cells, CD3+ and CD56+, are rare in peripheral blood mononuclear cells and are typically expanded in vitro derived from T-cells [63]. These cells co-express T-cell markers for CD3 and the NK marker CD56. CIK cells are a heterogeneous that include CD3- CD56+ NK cells, CD3+ CD56- effector T cells, and CD3+ CD56+ cells [64]. In vivo, CD3+ and CD56+ interact with NKG2D receptors and MHC-related ligands which mediate the tumor-killing activity [65].

CIK cells' ability to grow rapidly in vitro, in the presence of cytokines, with a robust antitumor activity and the ability to attack various kinds of cancer make CIK cells an attractive form of immunotherapy [66]. CIK cells also have the capacity of strengthening the immune system in patients with cancer [67]. The ability to travel to tumor site in vivo models with its various chemokine receptors makes CIK cells targeting more efficient [68] [69]. Autologous and allogeneic CIK cells have been studied in phase I/II clinical trials. In these trials, CIK cell immunotherapy has shown evidence of anti-tumor activity and limited toxicity [70]-[74].

\subsection{Oncolytic Viruses}

Viruses naturally produce a robust immune response including antigen presentation, inflammatory cytokines, and co-stimulation [75]. Viruses are typically recognized as foreign or non-self via pattern recognition receptors like toll receptors (TLR) of the innate immune response. Such recognition drives an immediate immune response of type 1 interferons which involve IFN- $\alpha$ and $\beta$ [76]-[78] and which in turn enhance the expression of CD40, CD80, CD83, and CD86 [79]-[81]. The pro-inflammatory response is then associated with expression of MHC and co-stimulatory molecules including IFN- $\alpha$ which is involved in stimulating CD8 cells associated with the activation of T-cells.

The recognition of antigens translated and presented after cell lysis has had limited effects on treating cancer thus far. Antigens associated with tumor cells have the potential to recruit innate and adaptive immune responses when presented after cell lysis. Jx-594 is an example of an oncolytic virus that infects hepatocellular carcinoma (HCC) in order to present cellular signals for an innate or adaptive immune response in addition to causing cell lysis [82]. The virus causes the expression of $\beta$-galactocidase which is a surrogate marker associated with viral detection in addition to being a granulocyte-macrophage colony-stimulating factor (GM-CSF) [83] [84]. Jx-594 also requires the activation of EGFR/RAS pathway for replication, essentially using the oncogenic metabolism to replicate in a manner that leads to cell death and presentation of the translated immunogenic antigens [83] [84].

\subsection{Monoclonal Antibody Immunotherapy}

Monoclonal antibodies (mAB) have been used in various ways to treat various cancers. The first FDA approved 
mAB was rituximab in 1997. Rituximab targets the CD20 of malignant B-cells and is also known to treat Hodgkin's lymphoma, neuroblastoma, and prostate cancer. Rituxmab is a nmAB that binds to tumor-associated antigens (TAA) and is associated with antibody dependent cell-mediated cytotoxicity (ADCC) [85] and complement dependent cytotoxicity [86] [87]. Other mABs like catumaxomab are bispecific and can crosslink to two different antigens in a manner that retains the capability of activating immune effector functions to treat malignant ascites in patients with epithelial cell adhesion molecules (EPCAM) tumors with specificity to CD3 [88] [89]. Y-ibritumamabtrixetan and I-tositumamab are $\mathrm{mAB}$ coupled with toxins or radionucleotide which can recognize CD20 targets [90] [91]. These antibodies are used to shuttle the toxins or radionucleotides in a way that can reduce the overall toxicity of drug administration by targeting specific cancer cells. Cetuximab is a chimeric IgG1 that has antigen specificity toward epidermal growth factor receptor (EGFR) and is used to inhibit cancer cell ability to transduce metabolic pathways associated with proliferation and/or survival in colorectal carcinoma [92] [93]. TRAILR2 or DR5 are targets of conatumumab which has the potential to initiate apoptosis of cancer cells by activating cytotoxic receptors of cancer cells [94]. It is currently in phase II clinical trial to treat colorectal carcinoma, lung cancer, and pancreatic cancer.

\section{Peptide Vaccines}

Peptide vaccines are short or long chains of amino acids which present an epitope to the immune system. These epitopes can include antigens expressed by various cancers which are used to stimulate an immune response that eventually targets cancer cells. The majority of peptide vaccines for cancer are designed stimulate CD8+ which has been associated in the eradication of tumors [95]-[99]. Other peptide vaccines induce an immune response by targeting CD4+ helper $\mathrm{T}$ lymphocytes with some anecdotal success with melanoma reactive CD4+ $\mathrm{T}$ cells [100].

The administration of peptide vaccines vary with regard to the length of the peptide and how many different varieties of peptides are used. Peptides are easy to make especially when compared to other forms of immunotherapy in addition to being well received in patients. Short peptides are usually 8 - 10 amino acids in length are recognized by CD8+ and eventually presented to class I MHC [101]. Long peptides are range from 13 - 18 amino acids long and are recognized by CD4+ T lymphocytes and presented to class II MHC [101]. Multiple peptides of various lengths are often used simultaneously to induce a more robust immune response and are immunogenic in $100 \%$ of the patients [102].

Although most peptides are able to induce an immune response in most patients, the effect on the immune system to attack tumor cells is limited with clinical response rates of 3\% - 5\% [103]. Presence of T-cells that recognize the antigen is no guaranty of a positive clinical outcome [102] [104]. This might have to do with the tumor micro environment not being hospitable to tumor associated immune response. In addition, many peptide vaccines lack secondary or tertiary structures and have the potential to be eradicated by proteases.

\section{Exosomes}

Exosomes are small membrane vesicles that usually range between 30 - $100 \mathrm{~nm}$ in diameter. They are typically in a saucer shape consisting of a lipid bilayer membrane with an internal compartment [105]. There are many different intercellular functions associated with exosomes including, exosome secreted by B cells can stimulate CD4+ T-cells [106]. There is also evidence to support that tumor antigens can be delivered from dendritic cells by exosomes to be presented to T cells in vivo and in vitro [107]-[109]. Cancer cells have the capacity to use exosomes in order to induce T-cell apoptosis associated with the CD95 ligand [110] [111]. Exosomes can essentially be used as a shuttle for antigen presentation to a host of immune cells. Clinical trials for inducing the immune system to target cancer cells involving exosome shuttling of granulocyte-macrophage colony-stimulating factor to induce an antitumor cytotoxic T lymphocytes [112] [113] was successful in inducing cytotoxic T-cell response [113].

\subsection{Gold Nanoparticle Vaccine}

Gold nanoparticles can specially accumulate within lymphocytes in addition to other tissues for delivering immune therapies like vaccines [114]-[117]. They come in a variety of sizes which have different properties with regard to absorption and localization of the nanoparticles [118]. The antigens and cytokines that are presented on 
the gold nanoparticles are protected from degradation [119]. Modulation of dendritic cells and T-cell activation in addition to other humoral responses is a function of gold nanoparticle mediated adjuvant delivery [119] [120]. Gold nanoparticles offer a persistent and strong immunological response and have been used deliver large payloads of antigens to given sites associated with the size of the nanoparticle [121]-[125]. It is important to note that the size of the nanoparticle with conjugated antigens increases the diameter substantially. A $30 \mathrm{~nm}$ in diameter gold nanoparticle conjugated with a peptide increases to a size of $80 \mathrm{~nm}$ [126]. This nanoparticle in particular was able to stimulate $\mathrm{T}$ cells at approximately 4 times that of free antigen peptide [126]. Goldnano particles of $10 \mathrm{~nm}$, with their associated antigen OVA, have the capacity to deliver a strong immune response after absorption into the skin in mice models, stimulating the anti-OVA IgG response [127]. Clinical studies at this moment are both limited in the amount in process as well as the low number of participants in the trials.

\subsection{IL-27 in Immunotherapy}

Interleukin 27 (IL-27) is in the IL-12 family of cytokines. IL-12 cytokines, secreted by DC and macrophages, are important in promoting cytotoxic T-cells (CTL) response in addition to differentiating $\mathrm{T}$ helper (Th) cells to type Th1 [128] [129]. DC secretes IL-27 when exposed to stimuli including type I or type II interferons and CD40 [130]-[132]. IL-27 acts to stimulate NK cytotoxicity and make tumor cells more vulnerable to cytotoxicity from NK cells [133] in addition to inducing tumor specific antibody response [134]. IL-27 works primarily through CD8+ cells to hinder tumor growth and metastasis. There is potential for tumor promoting activity by promoting Tr1 cells, from T cells, to further induce IL-10 which acts as a negative feedback for pro-inflammatory immune response [135] [136]. IL-27 can also repress DCs from producing cytokines in addition to its antigen-presenting abilities [137].

IL-27 has been shown to have anti-proliferative and anti-angiogenic properties for various kinds of cancers including melanoma [138] [139], acute myeloid leukemia [140], B acute lympoblastic leukemia [141], multiple myeloma [142], and B cell lymphomab [143]. IL-27 has tertiary effects associated with its immune-stimulatory activity with regard to its anit-tumor characteristics in colon carcinoma [144] [145], lung cancer [146], melanoma [147], neuroblastoma [148], and head and neck squamous cell carcinoma [149]. These studies also remarked on the low level of toxicity.

\section{Discussion}

There are many forms of effective immunotherapy for cancer with new forms coming out each year. The specificity and the toxicity when compared to chemotherapy and radiation is a significant improvement. While all immunotherapies are not created equal, there is still room to enhance each methodology respectively. As biomarkers become available targets and cancer biology becomes more in focus, the ability to target cancer cells without harming the rest of the body is becoming a reality. Although some immunotherapies did not effectively reduce the size of the tumor, many of them significantly increased the median survival time of the patient. The potential of using more than one form of immunotherapy per patient might become as popular as a patient being prescribed more than one drug to treat cancer.

Unfortunately, a significant amount of promising treatments are still in either phase I or phase II clinical trials and will not be available to the public for years to come. Another issue may involve the price associated with growing various lymphocytes before infusion. Many of the techniques associated with isolating and culturing cells require significant training and expertise to cultivate and administer the treatment. In addition, many hospitals are not equipped to handle the attention required for preserving lymphocytes. The storage and transfer from a lab bench to a hospital is also problematic.

As expressed in this article, there are many different modes to present antigens for cancer vaccines to aid the immune system in recognizing epitopes associated with various cancers. Cancer vaccines in particular are very intriguing and could serve as a method of treating cancers before they occur. Although that is not the current function of the cancer vaccines since they are targeted to the cancer that already exist in the patient, specific and common antigen biomarkers could be presented in a way that can harbinger the memory of a common cancerous biomarker.

It is very difficult to rank the various forms of immunotherapy against each other since the clinical data is limited. The methodologies can vary greatly from each form of immunotherapy, and the types of cancers are not uniform when comparing each study. More research is needed to see which set of circumstances immunotherapy 
works for a given patient with a specific type of cancer since a similar cancer diagnosis does not provide adequate information of the specific biology of cancer itself. Biopsy of the cancer should be examined to see which biomarkers are present and cross reference that information to either identify which immunotherapy would work or to make those antigens specific to that form of cancer for a cancer vaccine.

\section{References}

[1] Dunn, G.P., Old, L.J. and Schreiber, R.D. (2004) The Immunobiology of Cancer Immunosurveillance and Immunoediting. Immunity, 21, 137-148. http://dx.doi.org/10.1016/j.immuni.2004.07.017

[2] Swann, J.B. and Smyth, M.J. (2007) Immune Surveillance of Tumors. The Journal of Clinical Investigation, 117, 1137-1146. http://dx.doi.org/10.1172/JCI31405

[3] Cavallo, F., De Giovanni, C., Nanni, P., Forni, G. and Lollini, P.L. (2011) The Immune Hallmarks of Cancer. Cancer Immunology, Immunotherapy, 60, 319-326. http://dx.doi.org/10.1007/s00262-010-0968-0

[4] Fairweather, D. and Cihakova, D. (2009) Alternatively Activated Macrophages in Infection and Autoimmunity. Journal of Autoimmunity, 33, 222-230. http://dx.doi.org/10.1016/j.jaut.2009.09.012

[5] Kalinski, P. (2009) Dendritic Cells in Immunotherapy of Established Cancer: Roles of Signals 1, 2, 3 and 4 . Current Opinion in Investigational Drugs, 10, 526-535.

[6] Munk, M.E. and Emoto, M. (1995) Functions of T-Cell Subsets and Cytokines in Mycobacterial Infections. European Respiratory Journal, 20, 668-675.

[7] Parker, D.C. (1993) T Cell-Dependent B Cell Activation. Annual Review of Immunology, 11, 331-360. http://dx.doi.org/10.1146/annurev.iy.11.040193.001555

[8] Boon, T. and van der Bruggen, P. (1996) Human Tumor Antigens Recognized by T lym-phocytes. Journal of Experimental Medicine, 183, 725-729. http://dx.doi.org/10.1084/jem.183.3.725

[9] Breckpot, K. and Escors, D. (2009) Dendritic Cells for Active Anti-Cancer Immunother-Apy: Targeting Activation Pathways through Genetic Modification. Endocrine, Metabolic \& Immune Disorders Drug Targets, 9, 328-343.

[10] Campos-Perez, J., Rice, J., Escors, D., Collins, M., Paterson, A., Savelyeva, N. and Stevenson, F.K. (2013) DNA Fusion Vaccine Designs to Induce Tumor-Lytic CD8+ T-Cell Attack via the Immunodominant Cysteine-Containing Epitope of NY-ESO 1. International Journal of Cancer, 133, 1400-1407.

[11] DuPage, M., Mazumdar, C., Schmidt, L.M., Cheung, A.F. and Jacks, T. (2012) Expression of Tumour-Specific Antigens Underlies Cancer Immunoediting. Nature, 482, 405-409. http://dx.doi.org/10.1038/nature10803

[12] Van den Eynde, B.J. and van der Bruggen, P. (1997) T Cell Defined Tumor Antigens. Current Opinion in Immunology, 9, 684-693. http://dx.doi.org/10.1016/S0952-7915(97)80050-7

[13] Breckpot, K., Dullaers, M., Bonehill, A., van Meirvenne, S., Heirman, C., de Greef, C., van der Bruggen, P. and Thielemans, K. (2003) Lentivirally Transduced Dendritic Cells as a Tool for Cancer Immunotherapy. The Journal of Gene Medicine, 5, 654-667. http://dx.doi.org/10.1002/jgm.400

[14] Escors, D., Lopes, L., Lin, R., Hiscott, J., Akira, S., Davis, R.J. and Collins, M.K. (2008) Targeting Dendritic Cell Signalling to Regulate the Response to Immunisation. Blood, 111, 3050-3061. http://dx.doi.org/10.1182/blood-2007-11-122408

[15] Goold, H.D., Escors, D., Conlan, T.J., Chakraverty, R. and Bennett, C.L. (2011) Conventional Dendritic Cells Are Required for the Activation of Helper-Dependent CD8 T Cell Responses to a Model Antigen after Cutaneous Vaccination with Lentiviral Vectors. The Journal of Immunology, 186, 4565-4572. http://dx.doi.org/10.4049/jimmunol.1002529

[16] Tarbell, K.V., Yamazaki, S. and Steinman, R.M. (2006) The Interactions of Dendritic Cells with Antigen-Specific, Regulatory T Cells That Suppress Autoimmunity. Seminars in Immunology, 18, 93-102. http://dx.doi.org/10.1016/j.smim.2006.01.009

[17] Iwasaki, A. and Medzhitov, R. (2004) Toll-Like Receptor Control of the Adaptive Immune Responses. Nature Immunology, 5, 987-995. http://dx.doi.org/10.1038/ni1112

[18] Pasare, C. and Medzhitov, R. (2004) Toll-Dependent Control Mechanisms of CD4 T Cell Activation. Immunity, 21, 733-741. http://dx.doi.org/10.1016/j.immuni.2004.10.006

[19] Fife, B.T., Pauken, K.E., Eagar, T.N., Obu, T., Wu, J., Tang, Q., Azuma, M., Krummel, M.F. and Bluestone, J.A. (2009) Interactions between PD-1 and PD-L1 Promote Tolerance by Blocking the TCR-Induced Stop Signal. Nature Immunology, 10, 1185-1192. http://dx.doi.org/10.1038/ni.1790

[20] Karwacz, K., Bricogne, C., Macdonald, D., Arce, F., Bennett, C.L., Collins, M. and Escors, D. (2011) PD-L 1 Co-Stimulation Contributes to Ligand-Induced T Cell Receptor Down-Modulation on CD8 ${ }^{+}$T Cells. EMBO Molecular 
Medicine, 3, 581-592. http://dx.doi.org/10.1002/emmm.201100165

[21] Liechtenstein, T., Dufait, I., Lanna, A., Breckpot, K. and Escors, D. (2012) Modulating Co-Stimulation during Antigen Presentation to Enhance Cancer Immunotherapy. Immunology, Endocrine \& Metabolic Agents in Medicinal Chemistry, 12, 224-235.

[22] Escors, D., Bricogne, C., Arce, F., Kochan, G. and Karwacz, K. (2011) On the Mechanism of T Cell Receptor DownModulation and Its Physiological Significance. The Journal of Bioscience and Medicine, 1, No. 1.

[23] Zhan, X., Dravid, G., Ye, Z., Hammond, H., Shamblott, M., Gearhart, J., et al. (2004) Functional Antigen-Presenting Leucocytes Derived from Human Embryonic Stem Cells in vitro. The Lancet, 364, 163-171. http://dx.doi.org/10.1016/S0140-6736(04)16629-4

[24] Fairchild, P.J., Brook, F.A., Gardner, R.L., Graca, L., Strong, V., Tone, Y., et al. (2000) Directed Differentiation of Dendritic Cells from Mouse Embryonic Stem Cells. Current Biology, 10, 1515-1518. http://dx.doi.org/10.1016/S0960-9822(00)00824-1

[25] Vizcardo, R., Masuda, K., Yamada, D., Ikawa, T., Shimizu, K., Fujii, S., et al. (2013) Regeneration of Human Tumor Antigen-Specific T Cells from iPSCs Derived from Mature CD8 ${ }^{+}$T Cells. Cell Stem Cell, 12, 31-36. http://dx.doi.org/10.1016/j.stem.2012.12.006

[26] Knorr, D.A., Ni, Z., Hermanson, D., Hexum, M.K., Bendzick, L., Cooper, L.J., et al. (2013) Clinical-Scale Derivation of Natural Killer Cells from Human Pluripotent Stem Cells for Cancer Therapy. Stem Cells Translational Medicine, 2, 274-283. http://dx.doi.org/10.5966/sctm.2012-0084

[27] Seung, L.P., Rowley, D.A., Dubey. P. and Schreiber, H. (1995) Synergy between T-Cell Immunity and Inhibition of Paracrine Stimulation Causes Tumor Rejection. Proceedings of the National Academy of Sciences of the United States of America, 92, 6254-6258. http://dx.doi.org/10.1073/pnas.92.14.6254

[28] Antony, P.A., Piccirillo, C.A., Akpinarli, A., Finkelstein, S.E., Speiss, P.J., Surman, D.R., et al. (2005) CD8 ${ }^{+}$T Cell Immunity against a Tumor/Self-Antigen Is Augmented by CD4 ${ }^{+} \mathrm{T}$ Helper Cells and Hindered by Naturally Occurring T Regulatory Cells. The Journal of Immunology, 174, 2591-2601. http://dx.doi.org/10.4049/jimmunol.174.5.2591

[29] Gattinoni, L., Finkelstein, S.E., Klebanoff, C.A., Antony, P.A., Palmer, D.C., Spiess, P.J., et al. (2005) Removal of Homeostatic Cytokine Sinks by Lymphodepletion Enhances the Efficacy of Adoptively Transferred Tumor-Specific $\mathrm{CD}^{+}$T Cells. The Journal of Experimental Medicine, 202, 907-912. http://dx.doi.org/10.1084/jem.20050732

[30] Rosenberg, S.A. and Dudley, M.E. (2009) Adoptive Cell Therapy for the Treatment of Patients with Metastatic Melanoma. Current Opinion in Immunology, 21, 233-240. http://dx.doi.org/10.1016/j.coi.2009.03.002

[31] Rosenberg, S.A., Restifo, N.P., Yang, J.C., Morgan, R.A. and Dudley, M.E. (2008) Adoptive Cell Transfer: A Clinical Path to Effective Cancer Immunotherapy. Nature Reviews Cancer, 8, 299-308. http://dx.doi.org/10.1038/nrc2355

[32] Dudley, M.E. and Rosenberg, S.A. (2007) Adoptive Cell Transfer Therapy. Seminars in Oncology, 34, 524-531. http://dx.doi.org/10.1053/j.seminoncol.2007.09.002

[33] Dudley, M.E., Wunderlich, J.R., Yang, J.C., et al. (2005) Adoptive Cell Transfer Therapy Following Non-Myeloablative but Lymphodepleting Chemotherapy for the Treatment of Patients with Refractory Metastatic Melanoma. Journal of Clinical Oncology, 23, 2346-2357. http://dx.doi.org/10.1200/JCO.2005.00.240

[34] Dudley, M.E., Yang, J.C., Sherry, R., et al. (2008) Adoptive Cell Therapy for Patients with Metastatic Melanoma: Evaluation of Intensive Myeloablative Chemoradiation Preparative Regimens. Journal of Clinical Oncology, 26, 52335239. http://dx.doi.org/10.1200/JCO.2008.16.5449

[35] Schwartzentruber, D.J., Hom, S.S., Dadmarz, R., et al. (1994) In Vitro Predictors of Therapeutic Response in Melanoma Patients Receiving Tumor-Infiltrating Lymphocytes and Interleukin-2. Journal of Clinical Oncology, 12, 14751483.

[36] Aebersold, P., Hyatt, C., Johnson, S., et al. (1991) Lysis of Autologous Melanoma Cells by Tumor-Infiltrating Lymphocytes: Association with Clinical Response. Journal of the National Cancer Institute, 83, 932-937. http://dx.doi.org/10.1093/jnci/83.13.932

[37] Shen, X., Zhou, J., Hathcock, K.S., et al. (2007) Persistence of Tumor Infiltrating Lymphocytes in Adoptive Immunotherapy Correlates with Telomere Length. Journal of Immunotherapy, 30, 123-129. http://dx.doi.org/10.1097/01.cji.0000211321.07654.b8

[38] Zhou, J., Shen, X., Huang, J., Hodes, R.J., Rosenberg, S.A. and Robbins, P.F. (2005) Telomere Length of Transferred Lymphocytes Correlates with in vivo Persistence and Tumor Regression in Melanoma Patients Receiving Cell Transfer Therapy. Journal of Immunotherapy, 75, 7046-7052. http://dx.doi.org/10.4049/jimmunol.175.10.7046

[39] Robbins, P.F., Dudley, M.E., Wunderlich, J., et al. (2004) Cutting Edge: Persistence of Transferred Lymphocyte Clonotypes Correlates with Cancer Regression in Patients Receiving Cell Transfer Therapy. Journal of Immunotherapy, 173, 7125-7130. http://dx.doi.org/10.4049/jimmunol.173.12.7125 
[40] Tran, K.Q., Zhou, J., Durflinger, K.H., et al. (2008) Minimally Cultured Tumor-Infiltrating Lymphocytes Display Optimal Characteristics for Adoptive Cell Therapy. Journal of Immunotherapy, 31, 742-751. http://dx.doi.org/10.1097/CJI.0b013e31818403d5

[41] Powell Jr., D.J., Dudley, M.E., Robbins, P.F. and Rosenberg, S.A. (2005) Transition of Late-Stage Effector T Cells to CD27 ${ }^{+}$CD28 ${ }^{+}$Tumor-Reactive Effector Memory T Cells in Humans after Adoptive Cell Transfer Therapy. Blood, 105, 241-250. http://dx.doi.org/10.1182/blood-2004-06-2482

[42] Verheyden, S. and Demanet, C. (2008) NK Cell Receptors and Their Ligands in Leukemia. Leukemia, 22, 249-257. http://dx.doi.org/10.1038/sj.leu.2405040

[43] Vivier, E., Raulet, D.H., Moretta, A., Caligiuri, M.A., Zitvogel, L., Lanier, L.L., et al. (2011) Innate or Adaptive Immunity? The Example of Natural Killer Activating Ligands on Myeloid Cells. Science, 331, 44-49. http://dx.doi.org/10.1126/science.1198687

[44] Anfossi, N., Andre, P., Guia, S., Falk, C.S., Roetynck, S., Stewart, C.A., et al. (2006) Human NK Cell Education by Inhibitory Receptors for MHC Class I. Immunity, 25, 331-342. http://dx.doi.org/10.1016/j.immuni.2006.06.013

[45] Raulet, D.H. and Vance, R.E. (2006) Self Tolerance of Natural Killer Cells. Nature Reviews Immunology, 6, 520-531. http://dx.doi.org/10.1038/nri1863

[46] Kim, S., Poursine-Laurent, J., Truscott, S.M., Lybarger, L., Song, Y.-J., Yang, L., et al. (2005) Licensing of Natural Killer Cells by Host Major Histocompatibility Complex Class I Molecules. Nature, 436, 709-713.

[47] Gill, S., Vasey, A.E., De Souza, A., Baker, J., Smith, A.T., Kohrt, H.E., Florek, M., et al. (2012) Rapid Development of Exhaustion and Down-Regulation of Eomesodermin Limit the Antitumor Activity of Adoptively Transferred Murine Natural Killer Cells. Blood, 119, 5758-5768. http://dx.doi.org/10.1182/blood-2012-03-415364

[48] Helmlinger, G., Yuan, F., Dellian, M. and Jaia, R.K. (1997) Interstitial $\mathrm{pH}$ and $\mathrm{pO}_{2}$ Gradients in Solid Tumors in Vivo: High-Resolution Measurements Reveal a Lack of Correlation. Nature Medicine, 3, 177-182. http://dx.doi.org/10.1038/nm0297-177

[49] Parkhurst, M.R., Riley, J.R., Dudley, M.E. and Rosenberg, S.A. (2011) Adoptively Transferred Autologous Natural Killer Cells Persist in Circulation but Do Not Mediate Tumor Regression. Clinical Cancer Research, 17, 6287-6297. http://dx.doi.org/10.1158/1078-0432.CCR-11-1347

[50] Krause, S.W., Gastpar, R., Andresen, R., Gross, C., Ullrich, H., Thonigs, G., et al. (2004) Treatment of Colon Cancer Patients with ex vivo Heat Shock Protein 70 Peptide-Activated, Autologous Natural Killer Cells: A Clinical Phase I Trial. Clinical Cancer Research, 10, 3699-3707. http://dx.doi.org/10.1158/1078-0432.CCR-03-0683

[51] Motohashi, S., Ishikawa, A., Ishikawa, E., Otsuji, M., Iizasa, T., Haoaka, H., et al. (2006) A Phase I Study of ex vivo Expanded Natural Killer T Cells in Patients with Advanced and Recurrent Non-Small Lung Cancer. Clinical Cancer Research, 12, 6079-6086. http://dx.doi.org/10.1158/1078-0432.CCR-06-0114

[52] Koepsell, S.A., Miller, J.S. and McKenna Jr., D.H. (2013) Natural Killer Cells: A Review of Manufacturing and Clinical Utility. Transfusion, 53, 404-410. http://dx.doi.org/10.1111/j.1537-2995.2012.03724.X

[53] Miller, J.S., Soignier, Y., Panoskaltsis-Mortari, A., McNearney, S.A., Yun, G.H., Fautsch, S.K., et al. (2005) Successful Adoptive Transfer and in Vivo Expansion of Human Haploidentical NK Cells in Patients with Cancer. Blood, 105, 3051-3057. http://dx.doi.org/10.1182/blood-2004-07-2974

[54] Rubnitz, J.E., Inaba, H., Ribeiro, R.C., Pounds, S., Rooney, B., Bell, T., et al. (2010) NKAML: A Pilot Study to Determine the Safety and Feasibility of Haploidentical Natural Killer Cell Transplantation in Childhood Acute Myeloid Leukemia. Journal of Clinical Oncology, 28, 955-959. http://dx.doi.org/10.1200/JCO.2009.24.4590

[55] Taniguchi, M., Harada, M., Kojo, S., Nakayama, T. and Wakao, H. (2003) The Regulatory Role of Va14 NKT Cells in Innate and Acquired Immune Response. Annual Review of Immunology, 21, 483-513. http://dx.doi.org/10.1146/annurev.immunol.21.120601.141057

[56] Godfrey, D.I., MacDonald, H.R., Kronenberg, M., Smyth, M.J. and Van Kaer, L. (2004) NKT Cells: What's in a Name? Nature Reviews Immunology, 4, 231-237.

[57] Bendelac, A., Savage, P.B. and Teyton, L. (2007) The Biology of NKT Cells. Annual Review of Immunology, 25, 297336. http://dx.doi.org/10.1146/annurev.immunol.25.022106.141711

[58] Akutsu, Y., Nakayama, T., Harada, M., Kawano, T., Motohashi, S., Shimizu, E., et al. (2002) Expansion of Lung V Alpha 14 NKT Cells by Administration of Alpha-Galactosylceramide-Pulsed Dendritic Cells. Japanese Journal of Cancer Research, 93, 397-403.

[59] Motohashi, S., Kobayashi, S., Ito, T., Magara, K.K., Mikuni, O., Kamada, N., et al. (2002) Pre-Served IFN- $\alpha$ Production of Circulating Va24 NKT Cells in Primary Lung Cancer Patients. International Journal of Cancer, 102, 159-165. http://dx.doi.org/10.1002/ijc.10678

[60] Toura, I., Kawano, T., Akutsu, Y., Nakayama, T., Ochiai, T. and Taniguchi, M. (1999) Cutting Edge: Inhibition of 
Experimental Tumor Metastasis by Dendritic Cells Pulsed with $\alpha$-Galactosylceramide. The Journal of Immunology, 163, 2387-2391.

[61] Ishikawa, E., Motohashi, S., Ishikawa, A., Ito, T., Uchida, T., Kaneko, T., et al. (2005) Dendritic Cell Maturation by CD11c ${ }^{-} \mathrm{T}$ Cells and $\mathrm{V} \alpha 24^{+}$Natural Killer T-Cell Activation by $\alpha$-Galactosylceramide. International Journal of Cancer, 117, 265-273. http://dx.doi.org/10.1002/ijc.21197

[62] Motohashi, S., Okamoto, Y., Yoshino, I. and Nakayama, T. (2011) Anti-Tumor Immune Responses Induced by iNKT Cell-Based Immunotherapy for Lung Cancer and Head and Neck Cancer. Clinical Immunology, 140, 167-176. http://dx.doi.org/10.1016/j.clim.2011.01.009

[63] Schmidt-Wolf, I.G., Lefterova, P., Mehta, B.A., Fernandez, L.P., Huhn, D., Blume, K.G., Weissman, I.L. and Negrin, R.S. (1993) Phenotypic Characterization and Identification of Effector Cells Involved in Tumor Cell Recognition of Cytokineinduced Killer Cells. Experimental Hematology, 21, 1673-1679.

[64] Sumitran, S., Anderson, P., Widner, H. and Holgersson, J. (1999) Porcine Embryonic Brain Cell Cytotoxicity Mediated by Human Natural Killer Cells. Cell Transplantation, 8, 601-610.

[65] Mesiano, G., Todorovic, M., Gammaitoni, L., Leuci, V., Giraudo Diego, L., Carnevale-Schianca, F., Fagioli, F., Piacibello, W., Aglietta, M. and Sangiolo, D. (2012) Cytokine-Induced Killer (CIK) Cells as Feasible and Effective Adoptive Immunotherapy for the Treatment of Solid Tumors. Expert Opinion on Biological Therapy, 12, 673-684.

[66] Hontscha, C., Borck, Y., Zhou, H., Messmer, D. and Schmidt-Wolf, I.G.H. (2011) Clinical Trials on CIK Cells: First Report of the International Registry on CIK Cells (IRCC). Journal of Cancer Research and Clinical Oncology, 137, 305-310. http://dx.doi.org/10.1007/s00432-010-0887-7

[67] Schmidt-Wolf, I.G., Lefterova, P., Mehta, B.A., Fernandez, L.P., Huhn, D., Blume, K.G., et al. (1993) Phenotypic Characterization and Identification of Effector Cells Involved in Tumor Cell Recognition of Cytokine-Induced Killer Cells. Experimental Hematology, 21, 1673-1679.

[68] Nishimura, R., Baker, J., Beilhack, A., Zeiser, R., Olson, J.A., Sega, E.I., et al. (2008) In vivo Trafficking and Survival of Cytokine-Induced Killer Cells Resulting in Minimal GVHD with Retention of Antitumor Activity. Blood, 112, 2563-2574. http://dx.doi.org/10.1182/blood-2007-06-092817

[69] Thorne, S.H., Negrin, R.S. and Contag, C.H. (2006) Synergistic Antitumor Effects of Immune Cell-Viral Biotherapy. Science, 311, 1780-1784. http://dx.doi.org/10.1126/science.1121411

[70] Ren, X., Yu, J., Liu, H., Zhang, P., An, X., Zhang, N., et al. (2006) Th1 Bias in PBMC Induced by Multicycles of Auto-CIKs Infusion in Malignant Solid Tumor Patients. Cancer Biotherapy and Radiopharmaceuticals, 21, 22-33. http://dx.doi.org/10.1089/cbr.2006.21.22

[71] Su, X., Zhang, L., Jin, L., Ye, J., Guan, Z., Chen, R., et al. (2010) Immunotherapy with Cytokine-Induced Killer Cells in Metastatic Renal Cell Carcinoma. Cancer Biotherapy and Radiopharmaceuticals, 25, 465-470. http://dx.doi.org/10.1089/cbr.2010.0762

[72] Schmidt-Wolf, I.G., Finke, S., Trojaneck, B., Denkena, A., Lefterova, P., Schwella, N., et al. (1999) Phase I Clinical Study Applying Autologous Immunological Effector Cells Transfected with the Interleukin-2 Gene in Patients with Metastatic Renal Cancer, Colorectal Cancer and Lymphoma. British Journal of Cancer, 81, 1009-1016. http://dx.doi.org/10.1038/sj.bjc.6690800

[73] Li, H., Wang, C., Yu, J., Cao, S., Wei, F., Zhang, W., et al. (2009) Dendritic Cell Activated Cytokine-Induced Killer Cells Enhance the Anti-Tumor Effect of Chemotherapy on Non-Small Cell Lung Cancer in Patients after Surgery. Cytotherapy, 11, 1076-1083. http://dx.doi.org/10.3109/14653240903121252

[74] Takayama, T., Sekine, T., Makuuchi, M., Yamasaki, S., Kosuge, T., Yamamoto, J., et al. (2000) Adoptive Immunotherapy to Lower Postsurgical Recurrence Rates of Hepatocellular Carcinoma: A Randomised Trial. The Lancet, 356, 802-807. http://dx.doi.org/10.1016/S0140-6736(00)02654-4

[75] Kumar, H., Kawai, T. and Akira, S. (2011) Pathogen Recognition by the Innate Immune System. International Reviews of Immunology, 30, 16-34. http://dx.doi.org/10.3109/08830185.2010.529976

[76] Kawai, T. and Akira, S. (2010) The Role of Pattern-Recognition Receptors in Innate Immunity: Update on Toll-Like Receptors. Nature Immunology, 11, 373-384. http://dx.doi.org/10.1038/ni.1863

[77] Kawai, T. and Akira, S. (2011) Toll-Like Receptors and Their Cross Talk with Other Innate Receptors in Infection and Immunity. Immunity, 34, 637-650. http://dx.doi.org/10.1016/j.immuni.2011.05.006

[78] Kawai, T. and Akira, S. (2009) The Roles of TLRs, RLRs and NLR Sin Pathogen Recognition. International Immunology, 21, 317-337. http://dx.doi.org/10.1093/intimm/dxp017

[79] Hervas-Stubbs, S., Riezu-Boj, J.I., Gonzalez, I., Mancheno, U., Dubrot, J., Azpilicueta, A., et al. (2010) Effects of IFN-Alpha as a Signal-3 Cytokine on Human Naïve and Antigen-Experienced CD8 ${ }^{+}$T Cells. European Journal of Immunology, 40, 3389-3402. http://dx.doi.org/10.1002/eji.201040664 
[80] Montoya, M., Schiavoni, G., Mattei, F., Gresser, I., Belardelli, F., Borrow, P., et al. (2002) Type I Interferons Produced by Dendritic Cells Promote Their Phenotypic and Functional Activation. Blood, 99, 3263-3271. http://dx.doi.org/10.1182/blood.V99.9.3263

[81] Rudd, B.D., Luker, G.D., Luker, K.E., Peebles, R.S. and Lukacs, N.W. (2007) Type I Interferon Regulates Respiratory Virus Infected Dendritic Cell Maturation and Cytokine Production. Viral Immunology, 20, 531-540. http://dx.doi.org/10.1089/vim.2007.0057

[82] Hernandez-Gea, V., Alsinet, C. and Llovet, J.M. (2013) Oncolytic Immunotherapeutic Virus in HCC: Can It Compete with Molecular Therapies? Journal of Hepatology, 59, 882-884.

[83] Breitbach, C.J., Burke, J., Jonker, D., Stephenson, J., Haas, A.R., Chow, L.Q., et al. (2011) Intravenous Delivery of a Multi-Mechanistic Cancer-Targeted Oncolytic Poxvirus in Humans. Nature, 477, 99-102. http://dx.doi.org/10.1038/nature10358

[84] Breitbach, C.J., Arulanandam, R., De Silva, N., Thorne, S.H., Patt, R., Daneshmand, M., et al. (2012) Oncolytic Vaccinia Virus Disrupts Tumor-Associated Vasculature in Humans. Cancer Research, 73, 1-11.

[85] Winiarska, M., Glodkowska-Mrowka, E., Bil, J. and Golab, J. (2011) Molecular Mechanisms of the Antitumor Effects of Anti-CD20 Antibodies. Frontiers in Bioscience (Landmark Edition), 16, 277-306. http://dx.doi.org/10.2741/3688

[86] Dunkelberger, J.R. and Song, W.C. (2010) Complement and Its Role in Innate and Adaptive Immune Responses. Cell Research, 20, 34-50. http://dx.doi.org/10.1038/cr.2009.139

[87] Zipfel, P.F. and Skerka, C. (2009) Complement Regulators and Inhibitory Proteins. Nature Reviews Immunology, 9, 729-740.

[88] Seimetz, D. (2011) Novel Monoclonal Antibodies for Cancer Treatment: The Trifunctional Antibody Catumaxomab $\left(\right.$ Removab $^{\circledR}$ ). Journal of Cancer, 2, 309-316. http://dx.doi.org/10.7150/jca.2.309

[89] Armeanu-Ebinger, S., Hoh, A., Wenz, J. and Fuchs, J. (2013) Targeting EpCAM (CD326) for Immunotherapy in Hepatoblastoma. Oncoimmunology, 2, e22620. http://dx.doi.org/10.4161/onci.22620

[90] Vacchelli, E., Galluzzi, L., Fridman, W.H., Galon, J., Sautès-Fridman, C., Tartour, E. and Kroemer, G. (2012) Trial Watch: Chemotherapy with Immunogenic Cell Death Inducers. Oncoimmunology, 1, 179-188. http://dx.doi.org/10.4161/onci.1.2.19026

[91] Kottschade, L.A., Suman, V.J., Perez, D.G., McWilliams, R.R., Kaur, J.S., Amatruda 3rd, T.T., Geoffroy, F.J., Gross, H.M., Cohen, P.A., Jaslowski, A.J., et al. (2013) A Randomized Phase 2 Study of Temozolomide and Bevacizumab or Nab-Paclitaxel, Carboplatin and Bevacizumab in Patients with Unresectable Stage IV Melanoma: A North Central Cancer Treatment Group Study, N0775. Cancer, 119, 586-592. http://dx.doi.org/10.1002/cncr.27760

[92] Weiner, L.M., Belldegrun, A.S., Crawford, J., Tolcher, A.W., Lockbaum, P., Arends, R.H., Navale, L., Amado, R.G., Schwab, G. and Figlin, R.A. (2008) Dose and Schedule Study of Panitumumab Monotherapy in Patients with Advanced Solid Malignancies. Clinical Cancer Research, 14, 502-508. http://dx.doi.org/10.1158/1078-0432.CCR-07-1509

[93] Ming Lim, C., Stephenson, R., Salazar, A.M. and Ferris, R.L. (2013) TLR3 Agonists Improve the Immunostimulatory Potential of Cetuximab against EGFR ${ }^{+}$Head and Neck Cancer Cells. Oncoimmunology, 2, e24677. http://dx.doi.org/10.4161/onci.24677

[94] Kaplan-Lefko, P.J., Graves, J.D., Zoog, S.J., Pan, Y., Wall, J., Branstetter, D.G., Moriguchi, J., Coxon, A., Huard, J.N., Xu, R., et al. (2010) Conatumumab, a Fully Human Agonist Antibody to Death Receptor 5, Induces Apoptosis via Caspase Activation in Multiple Tumor Types. Cancer Biology Therapy, 9, 618-631. http://dx.doi.org/10.4161/cbt.9.8.11264

[95] Fearon, E.R., Pardoll, D.M., Itaya, T., et al. (1990) Interleukin-2 Production by Tumor Cells Bypasses T Helper Function in the Generation of an Antitumor Response. Cell, 60, 397-403. http://dx.doi.org/10.1016/0092-8674(90)90591-2

[96] Golumbek, P.T., Lazenby, A.J., Levitsky, H.I., et al. (1991) Treatment of Established Renal Cancer by Tumor Cells Engineered to Secrete Interleukin-4. Science, 254, 713-716. http://dx.doi.org/10.1126/science.1948050

[97] Dranoff, G., Jaffee, E., Lazenby, A., et al. (1993) Vaccination with Irradiated Tumor Cells Engineered to Secrete Murine Granulocyte-Macrophage Colony-Stimulating Factor Stimulates Potent, Specific and Long-Lasting Anti-Tumor Immunity. Proceedings of the National Academy of Sciences of the United States of America, 90, 3539-3543. http://dx.doi.org/10.1073/pnas.90.8.3539

[98] Kast, W.M., Offringa, R., Peters, P.J., et al. (1989) Eradication of Adenovirus E1-Induced Tumors by E1A-Specific Cytotoxic T Lymphocytes. Cell, 59, 603-614. http://dx.doi.org/10.1016/0092-8674(89)90006-8

[99] Greenberg, P.D. and Riddell, S.R. (1995) Principles for Adoptive T Cell Therapy of Human Viral Diseases. Annual Review in Immunology, 13, 545-586. http://dx.doi.org/10.1146/annurev.iy.13.040195.002553

[100] Hunder, N.N., Wallen, H., Cao, J., et al. (2008) Treatment of Metastatic Melanoma with Autologous CD4 ${ }^{+}$T Cells 
against NY-ESO-1. The New England Journal of Medicine, 358, 2698-2703.

http://dx.doi.org/10.1056/NEJMoa0800251

[101] Slingluff, C.L. (2011) The Present and Future of Peptide Vaccines for Cancer: Single Or Multiple, Long or Short, Alone or in Combination. The Cancer Journal, 17, 343-350. http://dx.doi.org/10.1097/PPO.0b013e318233e5b2

[102] Slingluff Jr., C.L., Petroni, G.R., Chianese-Bullock, K.A., et al. (2007) Immunologic and Clinical Outcomes of a Randomized Phase II Trial of Two Multipeptide Vaccines for Melanoma in the Adjuvant Setting. Clinical Cancer Research, 13, 6386-6395. http://dx.doi.org/10.1158/1078-0432.CCR-07-0486

[103] Rosenberg, S.A., Yang, J.C. and Restifo, N.P. (2004) Cancer Immunotherapy: Moving beyond Current Vaccines. Nature Medicine, 10, 909-915. http://dx.doi.org/10.1038/nm1100

[104] Kirkwood, J.M., Lee, S., Land, S., et al. (2004) E1696: Final Analysis of the Clinical and Immunological Results of a Multicenter ECOG Phase II Trial of Multi-Epitope Peptide Vaccination for Stage IV Melanoma with MART-1 (27-35), gp100 (209-217, 210M) and Tyrosinase (368-376, 370D) (MGT) +/- IFNa2b and GM-CSF. Journal of Clinical Oncology, 22, 7502.

[105] Thery, C., Zitvogel, L. and Amigorena, S. (2002) Exosomes: Composition, Biogenesis and Function. Nature Reviews Immunology, 2, 569-579.

[106] Raposo, G., Nijman, H.W., Stoorvogel, W., et al. (1996) B Lymphocytes Secrete Antigen-Presenting Vesicles. The Journal of Experimental Medicine, 183, 1161-1172. http://dx.doi.org/10.1084/jem.183.3.1161

[107] Mears, R., Craven, R.A., Hanrahan, S., et al. (2004) Proteomic Analysis of Melanoma-Derived Exosomes by Two-Dimensional Polyacrylamide Gel Electrophoresis and Mass Spectrometry. Proteomics, 4, 4019-4031. http://dx.doi.org/10.1002/pmic.200400876

[108] Zitvogel, L., Regnault, A., Lozier, A., et al. (1998) Eradication of Established Murine Tumors Using a Novel Cell-Free Vaccine: Dendritic Cell-Derived Exosomes. Nature Medicine, 4, 594-600. http://dx.doi.org/10.1038/nm0598-594

[109] Chen, W., Wang, J., Shao, C., et al. (2006) Efficient Induction of Antitumor T Cell Immunity by Exosomes Derived from Heat-Shocked Lymphoma Cells. European Journal of Immunology, 36, 1598-1607. http://dx.doi.org/10.1002/eji.200535501

[110] Huber, V., Fais, S., Iero, M., et al. (2005) Human Colorectal Cancer Cells Induce T-Cell Death through Release of Proapoptotic Microvesicles: Role in Immune Escape. Gastroenterology, 128, 1796-804. http://dx.doi.org/10.1053/j.gastro.2005.03.045

[111] Andreola, G., Rivoltini, L., Castelli, C., et al. (2002) Induction of Lymphocyte Apoptosis by Tumor Cell Secretion of FasL-Bearing Microvesicles. The Journal of Experimental Medicine, 195, 1303-1316. http://dx.doi.org/10.1084/jem.20011624

[112] Weber, J., Sondak, V.K., Scotland, R., et al. (2003) Granulocyte-Macrophage-Colony-Stimulating Factor Added to a Multi-Peptide Vaccine for Resected Stage II Melanoma. Cancer, 97, 186-200. http://dx.doi.org/10.1002/cncr.11045

[113] Hodge, J.W., Chakraborty, M., Kudo-Saito, C., et al. (2005) Multiple Costimulatory Modalities Enhance CTL Avidity. The Journal of Immunology, 174, 5994-6004. http://dx.doi.org/10.4049/jimmunol.174.10.5994

[114] Jewell, C.M., Bustamante Lop'ez, S.C. and Irvine, D.J. (2011) In Situ Engineering of the Lymph Node Microenvironment via Intranodal Injection of Adjuvant-Releasing Polymer Particles. Proceedings of the National Academy of Sciences of the United States of America, 108, 15745-15750. http://dx.doi.org/10.1073/pnas.1105200108

[115] Khlebtsov, N. and Dykman, L. (2011) Biodistribution and Toxicity of Engineered Gold Nanoparticles: A Review of in vitro and in vivo Studies. Chemical Society Reviews, 40, 1647-1671. http://dx.doi.org/10.1039/c0cs00018c

[116] Almeida, J.P.M., Chen, A.L., Foster, A. and Drezek, R. (2011) In Vivo Biodistribution of Nanoparticles. Nanomedicine, 6, 815-835. http://dx.doi.org/10.2217/nnm.11.79

[117] Alexis, F., Pridgen, E., Molnar, L.K. and Farokhzad, O.C. (2008) Factors Affecting the Clearance and Biodistribution of Polymeric Nanoparticles. Molecular Pharmaceutics, 5, 505-515. http://dx.doi.org/10.1021/mp800051m

[118] Zhang, G.D., Yang, Z., Lu, W., Zhang, R., Huang, Q., Tian, M., et al. (2009) Influence of Anchoring Ligands and Particle Size on the Colloidal Stability and in Vivo Biodistribution of Polyethylene Glycol-Coated Gold Nanoparticles in Tumor-Xenografted Mice. Biomaterials, 30, 1928-1936. http://dx.doi.org/10.1016/j.biomaterials.2008.12.038

[119] Cruz, L.J., Rueda, F., Cordobilla, B., Simon, L., Hosta, L., Albericio, F., et al. (2011) Targeting Nanosystems to Human DCs via Fc Receptor as an Effective Strategy to Deliver Antigen for Immunotherapy. Molecular Pharmaceutics, 8, 104-116. http://dx.doi.org/10.1021/mp100178k

[120] Cruz, L.J., Tacken, P.J., Rueda, F., Domingo, J.C., Albericio, F. and Figdor, C.G. (2012) Targeting Nanoparticles to Dendritic Cells for Immunotherapy. Methods in Enzymology, 509, 143-163.

[121] Niikura, K., Matsunaga, T., Suzuki, T., Kobayashi, S., Yamaguchi, H., Orba, Y., et al. (2013) Gold Nanoparticles as a 
Vaccine Platform: Influence of Size and Shape on Immunological Responses in Vitro and in Vivo. ACS Nano, 7, 39263938. http://dx.doi.org/10.1021/nn3057005

[122] Almeida, J.P.M., Figueroa, E.R. and Drezek, R.A. (2014) Gold Nanoparticle Mediated Cancer Immunotherapy. Nanomedicine: Nanotechnology, Biology, and Medicine, 10, 503-514.

[123] Safari, D., Marradi, M., Chiodo, F., Dekker, H.A.T., Shan, Y., Adamo, R., et al. (2012) Gold Nanoparticles as Carriers for a Synthetic Streptococcus Pneumonia Type 14 Conjugate Vaccine. Nanomedicine, 7, 651-662. http://dx.doi.org/10.2217/nnm.11.151

[124] Pokharkar, V., Bhumkar, D., Suresh, K., Shinde, Y., Gairola, S. and Jadhav, S.S. (2011) Gold Nanoparticles as a Potential Carrier for Transmucosal Vaccine Delivery. Journal of Biomedical Nanotechnology, 7, 57-59. http://dx.doi.org/10.1166/jbn.2011.1200

[125] Chen, Y.S., Hung, Y.C., Lin, W.H. and Huang, G.S. (2010) Assessment of Gold Nanoparticles as a Size-Dependent Vaccine Carrier for Enhancing the Antibody Response against Synthetic Foot-and-Mouth Disease Virus Peptide. Nanotechnology, 21, Article ID: 195101.

[126] Lin, A.Y., Mattos Almeida, J.P., Bear, A., Liu, N., Luo, L., Foster, A.E., et al. (2013) Gold Nanoparticle Delivery of Modified CpG Stimulates Macrophages and Inhibits Tumor Growth for Enhanced Immunotherapy. PLoS ONE, 8, e63550. http://dx.doi.org/10.1371/journal.pone.0063550

[127] Huang, Y., Yu, F., Park, Y.-S., Wang, J., Shin, M.-C., Chung, H.S., et al. (2010) Coadministration of Protein Drugs with Gold Nanoparticles to Enable Percutaneous Delivery. Biomaterials, 31, 9086-9091. http://dx.doi.org/10.1016/j.biomaterials.2010.08.046

[128] Curtsinger, J.M., Lins, D.C. and Mescher, M.F. (2003) Signal 3 Determines Tolerance versus Full Activation of Naive CD8 T Cells: Dissociating Proliferation and Development of Effector Function. The Journal of Experimental Medicine, 197, 1141-1151. http://dx.doi.org/10.1084/jem.20021910

[129] Murugaiyan, G., Agrawal, R., Mishra, G.C., Mitra, D. and Saha, B. (2007) Differential CD40/CD40L Expression Results in Counteracting Antitumor Immune Response. The Journal of Immunology, 178, 2047-2055. http://dx.doi.org/10.4049/jimmunol.178.4.2047

[130] Murugaiyan, G., Mittal, A. and Weiner, H.L. (2010) Identification of an IL-27/Osteopontin Axis in Dendritic Cells and Its Modulation by IFN-g Limits IL-17 Mediated Autoimmune Inflammation. Proceedings of the National Academy of Sciences of the United States of America, 107, 11495-11500. http://dx.doi.org/10.1073/pnas.1002099107

[131] Shinohara, M.L., Kim, J.H., Garcia, V.A. and Cantor, H. (2008) Engagement of the Type I Interferon Receptor on Dendritic Cells Inhibits T Helper 17 Cell Development: Role of Intracellular Osteopontin. Immunity, 29, 68-78. http://dx.doi.org/10.1016/j.immuni.2008.05.008

[132] Schnurr, M., Toy, T., Shin, A., Wagner, M., Cebon, J. and Maraskovsky, E. (2005) Extranuclear Nucleotide Signaling by P2 Receptors Inhibits IL-12 and Enhances IL-23 Expression in Human Dendritic Cells: A Novel Role for cAMP Pathway. Blood, 105, 1582-1589. http://dx.doi.org/10.1182/blood-2004-05-1718

[133] Liu, L., Wang, S., Shan, B., et al. (2008) IL-27-Mediated Activation of Natural Killer Cells and Inflammation Produced Antitumour Effects for Human Oesophageal Carcinoma Cells. Scandinavian Journal of Immunology, 68, 22-29. http://dx.doi.org/10.1111/j.1365-3083.2008.02111.x

[134] Matsui, M., Kishida, T., Nakano, H., Yoshimoto, K., Shin-Ya, M., Shimada, T., Nakai, S., Imanishi, J., Yoshimoto, T., Hisa, Y. and Mazda, O. (2009) Interleukin-27 Activates Natural Killer Cells and Suppresses NK-Resistant Head and Neck Squamous Cell Carcinoma through Inducing Antibody-Dependent Cellular Cytotoxicity. Cancer Research, 69, 2523-2530. http://dx.doi.org/10.1158/0008-5472.CAN-08-2793

[135] Pot, C., Apetoh, L., Awasthi, A. and Kuchroo, V.K. (2011) Induction of Regulatory Tr1 Cells and Inhibition of T(H)17 Cells by IL-27. Seminars in Immunology, 23, 438-445. http://dx.doi.org/10.1016/j.smim.2011.08.003

[136] Awasthi, A., Carrier, Y., Peron, J.P., Bettelli, E., Kamanaka, M., Flavell, R.A., Kuchroo, V.K., Oukka, M. and Weiner, H.L. (2007) A Dominant Function for Interleukin 27 in Generating Interleukin 10-Producing Anti-Inflammatory T Cells. Nature Immunology, 8, 1380-1389. http://dx.doi.org/10.1038/ni1541

[137] Wang, S., Miyazaki, Y., Shinozaki, Y. and Yoshida, H. (2007) Augmentation of Antigen-Presenting and Th1-Promoting Functions of Dendritic Cells by WSX-1 (IL-27R) Deficiency. The Journal of Immunology, 179, 6421-6428. http://dx.doi.org/10.4049/jimmunol.179.10.6421

[138] Yoshimoto, T., Morishima, N., Mizoguchi, I., Shimizu, M., Nagai, H., Oniki, S., Oka, M., Nishigori, C. and Mizuguchi, J. (2008) Antiproliferative Activity of IL-27 on Melanoma. The Journal of Immunology, 180, 6527-6535. http://dx.doi.org/10.4049/jimmunol.180.10.6527

[139] Shimizu, M., Shimamura, M., Owaki, T., Asakawa, M., Fujita, K., Kudo, M., Iwakura, Y., Takeda, Y., Luster, A.D., Mizuguchi, J. and Yoshimoto, T. (2006) Antiangiogenic and Antitumor Activities of IL-27. The Journal of Immunology, 176, 7317-7324. http://dx.doi.org/10.4049/jimmunol.176.12.7317 
[140] Zorzoli, A., Di Carlo, E., Cocco, C., Ognio, E., Ribatti, D., Ferretti, E., Dufour, C., Locatelli, F., Montagna, D. and Airoldi, I. (2012) Interleukin-27 Inhibits the Growth of Pediatric Acute Myeloid Leukemia in NOD/SCID/Il2 $\mathrm{rg}^{-/ /}$Mice. Clinical Cancer Research, 18, 1630-1640. http://dx.doi.org/10.1158/1078-0432.CCR-11-2432

[141] Canale, S., Cocco, C., Frasson, C., Seganfreddo, E., Di Carlo, E., Ognio, E., Sorrentino, C., Ribatti, D., Zorzoli, A., Basso, G., Dufour, C. and Airoldi, I. (2011) Interleukin-27 Inhibits Pediatric B-Acute Lymphoblastic Leukemia Cell Spreading in a Preclinical Model. Leukemia, 25, 1815-1824. http://dx.doi.org/10.1038/leu.2011.158

[142] Cocco, C., Giuliani, N., Di Carlo, E., Ognio, E., Storti, P., Abeltino, M., Sorrentino, C., Ponzoni, M., Ribatti, D. and Airoldi, I. (2010) Interleukin-27 Acts as Multifunctional Antitumor Agent in Multiple Myeloma. Clinical Cancer Research, 16, 4188-4197. http://dx.doi.org/10.1158/1078-0432.CCR-10-0173

[143] Cocco, C., Di Carlo, E., Zupo, S., Canale, S., Zorzoli, A., Ribatti, D., Morandi, F., Ognio, E. and Airoldi, I. (2012) Complementary IL-23 and IL-27 Anti-Tumor Activities Cause Strong Inhibition of Human Follicular and Diffuse Large B-Cell Lymphoma Growth in Vivo. Leukemia, 26, 1365-1374. http://dx.doi.org/10.1038/leu.2011.363

[144] Hisada, M., Kamiya, S., Fujita, K., Belladonna, M.L., Aoki, T., Koyanagi, Y., Mizuguchi, J. and Yoshimoto, T. (2004) Potent Antitumor Activity of Interleukin-27. Cancer Research, 64, 1152-1156. http://dx.doi.org/10.1158/0008-5472.CAN-03-2084

[145] Chiyo, M., Shimozato, O., Yu, L., Kawamura, K., Iizasa, T., Fujisawa, T. and Tagawa, M. (2005) Expression of IL-27 in Murine Carcinoma Cells Produces Antitumor Effects and Induces Protective Immunity in Inoculated Host Animals. International Journal of Cancer, 115, 437-442. http://dx.doi.org/10.1002/ijc.20848

[146] Ho, M.Y., Leu, S.J., Sun, G.H., Tao, M.H., Tang, S.J. and Sun, K.H. (2009) IL-27 Directly Restrains Lung Tumorigenicity by Suppressing Cyclooxygenase-2-Mediated Activities. The Journal of Immunology, 183, 6217-6226. http://dx.doi.org/10.4049/jimmunol.0901272

[147] Oniki, S., Nagai, H., Horikawa, T., Furukawa, J., Belladonna, M.L., Yoshimoto, T., Hara, I. and Nishigori, C. (2006) Interleukin-23 and Interleukin-27 Exert Quite Different Antitumor and Vaccine Effects on Poorly Immunogenic Melanoma. Cancer Research, 66, 6395-6404. http://dx.doi.org/10.1158/0008-5472.CAN-05-4087

[148] Salcedo, R., Stauffer, J.K., Lincoln, E., Back, T.C., Hixon, J.A., Hahn, C., Shafer-Weaver, K., Malyguine, A., Kastelein, R. and Wigginton, J.M. (2004) IL-27 Mediates Complete Regression of Orthotopic Primary and Metastatic Murine Neuroblastoma Tumors: Role for CD8 ${ }^{+}$T Cells. The Journal of Immunology, 173, 7170-7182. http://dx.doi.org/10.4049/jimmunol.173.12.7170

[149] Matsui, M., Kishida, T., Nakano, H., Yoshimoto, K., Shin-Ya, M., Shimada, T., Nakai, S., Imanishi, J., Yoshimoto, T., Hisa, Y. and Mazda, O. (2009) Interleukin-27 Activates Natural Killer Cells and Suppresses NK-Resistant Head and Neck Squamous Cell Carcinoma through Inducing Antibody-Dependent Cellular Cytotoxicity. Cancer Research, 69, 2523-2530. http://dx.doi.org/10.1158/0008-5472.CAN-08-2793 
Scientific Research Publishing (SCIRP) is one of the largest Open Access journal publishers. It is currently publishing more than 200 open access, online, peer-reviewed journals covering a wide range of academic disciplines. SCIRP serves the worldwide academic communities and contributes to the progress and application of science with its publication.

Other selected journals from SCIRP are listed as below. Submit your manuscript to us via either submit@scirp.org or Online Submission Portal.
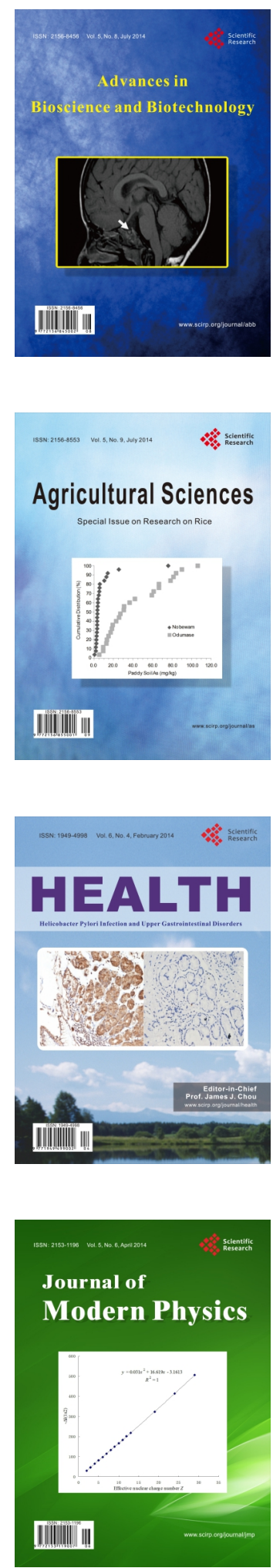
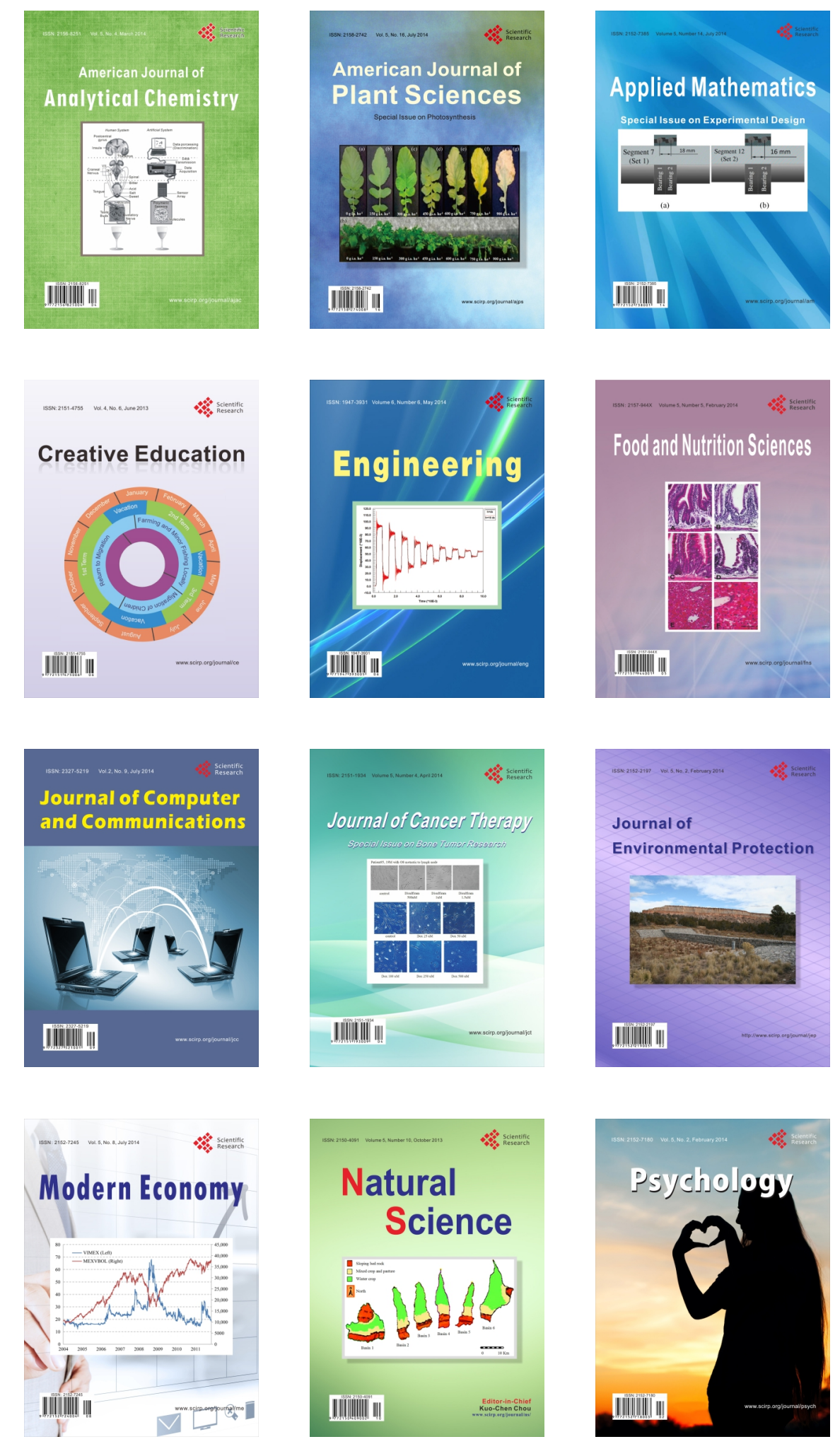